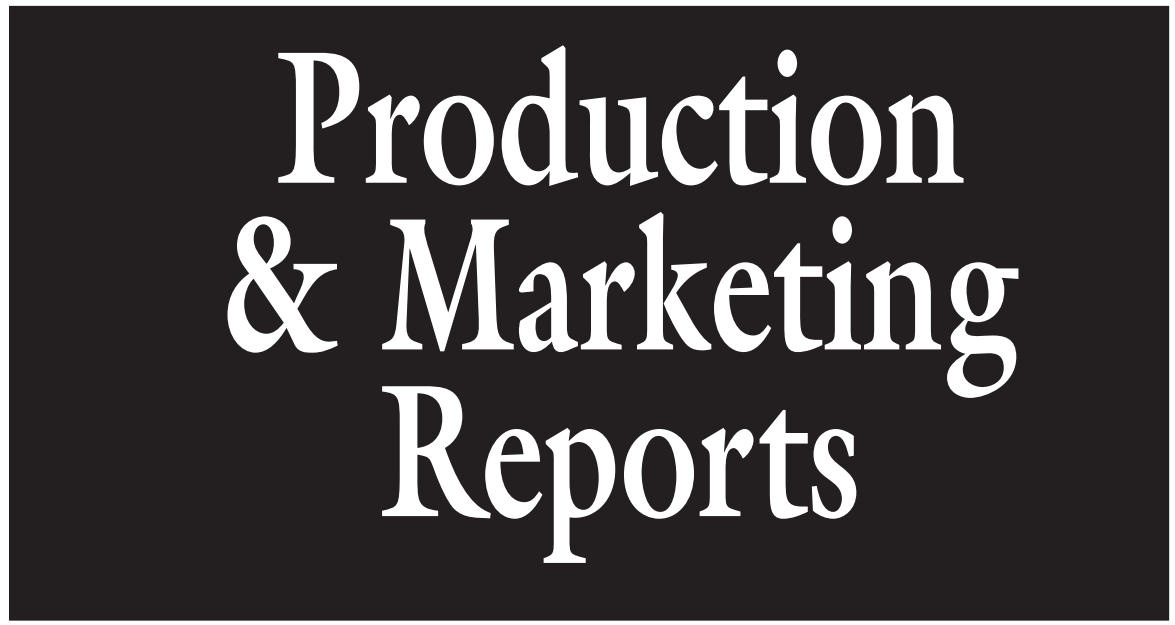

\section{Estimated Costs of Producing, Harvesting, and Marketing Blackberries in the Southeastern United States}

\author{
Charles D. Safley ${ }^{1}$, Otilia Boldea ${ }^{2}$, and Gina E. Fernandez ${ }^{3}$
}

AdDitional INDEX wORDs. $R u b u s$, economics, budget, inputs, outputs

SUMMARY. This study identified the costs associated with growing, harvesting, and marketing blackberries ( $R u b u s$ subgenus $R u b u s$ ) and estimated the revenues and breakeven yields for various combinations of pick-your-own (PYO) and wholesale blackberry prices. The total cost of producing, harvesting, and marketing the blackberries was estimated to be $\$ 15,514 /$ acre if the marketable yield was 10,000 $\mathrm{lb} /$ acre in the second year of production, and $\$ 19,561 /$ acre if the yield was $12,500 \mathrm{lb} /$ acre. Labor was the greatest expense category after the planting started producing fruit, totaling $\$ 13,739 /$ acre, or $70 \%$ of the total costs, when full production was reached in the third year. Net revenues for varying combinations of PYO and wholesale market prices and yields were estimated, assuming that half of the marketable fruit would be sold at a PYO operation and the remaining half sold to wholesale markets. This analysis showed that if growers received $\$ 1.25$ and $\$ 2.50 / 1 b$ for PYO and wholesale fruit, respectively, they would have to sell a minimum of $10,066 \mathrm{lb} /$ acre to cover the estimated costs for the third through the ninth years. A return to land and management of $\$ 3876 /$ acre would be realized if growers received $\$ 1.25 / 1 b$ for PYO and $\$ 2.50$ / $\mathrm{lb}$ wholesale with yields of $12,500 \mathrm{lb} /$ acre. Profitability analysis reveals that blackberry production using recommended practices can be a profitable venture. The annual net cash flow is positive after the planting is established and enough revenues are projected to be generated to cover start-up expenses in the fifth year.

$\mathrm{B}$ lackberry production is on the rise in the southeastern United States due to the consumerdriven demand for this high-value crop and to the recent release of cultivars with superior fruit quality. Although

${ }^{1}$ Professor, Department of Agricultural and Resource Economics, North Carolina State University, Raleigh, NC 27695-8109; e-mail: charles_safley@ncsu.edu

${ }^{2}$ Graduate Research Assistant, Department of Agricultural and Resource Economics, North Carolina State University, Raleigh, NC 27695-8109.

${ }^{3}$ Associate Professor, Department of Horticultural Science, North Carolina State University, Raleigh NC 27695-7609. the total number of acres of this highvalue crop in North Carolina (NC) is small relative to other horticultural crops, there was a $60 \%$ increase in total acreage between 1997 and $2002(78$ acres in 1997 and 125 acres in 2002) and a $27 \%$ increase in the number of farms growing blackberries ( 102 farms in 1997 and 130 farms in 2002) (C. Hayes, personal communication). Other states in the region have experienced significant growth as well. This is corroborated by the University of Arkansas blackberry breeding program, the origin of most of the cultivars currently grown in the region. The royalty income from sales of their cultivars increased 320\% from 1990 to 2000 (J.R. Clark, personal communication). Furthermore, based on conversations and visits with new growers, the total acreage is likely to increase within the next few years. Current and potential blackberry growers not only need production information but also financial information to make informed decisions about entering, leaving, or expanding existing farming operations. Like all businesses, the primary objective of growing blackberries should be to make a profit.

Budgets for producing blackberries are available (Ernst et al., 2001; Perry et al., 2002; Pritts and Handley, 1989). However, these budgets were developed for different climates, cultivars, and production systems. In addition, our budget includes a breakeven analysis, which allows growers to determine price and yield necessary to recoup their costs, while the budget by Ernst et al. (2001) does not. Therefore, the purpose of this publication is to provide information about the costs and returns of growing, harvesting, and marketing blackberries for the southeastern U.S. The data are intended to serve as guides to assist individuals entering the blackberry industry and help those who are currently growing blackberries to make more informed management decisions.

The specific objectives of this study were to: 1) estimate the typical costs associated with growing, harvesting, and marketing blackberries, 2 ) evaluate the effect of varying price and productivity (yield), and 3 ) evaluate the profitability of establishing a blackberry planting.

\begin{tabular}{llll}
\hline $\begin{array}{l}\text { Units } \\
\begin{array}{l}\text { To convert U.S. to SI, } \\
\text { multiply by }\end{array}\end{array}$ & U.S. unit & SI unit & $\begin{array}{l}\text { To convert SI to U.S., } \\
\text { multiply by }\end{array}$ \\
\hline 0.4047 & $\mathrm{acre}(\mathrm{s})$ & $\mathrm{ha}$ & 2.4711 \\
0.3048 & $\mathrm{ft}$ & $\mathrm{m}$ & 3.2808 \\
0.7457 & horsepower & $\mathrm{kJ} \cdot \mathrm{s}^{-1}$ & 1.3410 \\
0.4536 & $\mathrm{lb}$ & $\mathrm{kg}$ & 2.2046 \\
1.1209 & $\mathrm{lb} / \mathrm{acre}$ & $\mathrm{kg} \cdot \mathrm{ha}^{-1}$ & 0.8922 \\
0.9072 & ton(s) & $\mathrm{t}$ & 1.1023
\end{tabular}




\section{Materials and methods}

Procedure and assumptions. A complete cost model was developed for a 1-acre blackberry planting, using Microsoft Excel (Microsoft Corp., Redmond, Wash.), to address the objectives of this study. Production practices were based on typical management procedures recommended by production specialists and farmers who are currently operating commercial blackberry operations. The monthly production sequence; the equipment, material, and labor input requirements needed to complete each operation; and the estimated costs per acre were developed for a representative farm in the southeastern U.S.

The estimated hours of labor required for each of the operations that involves machinery and equipment were increased by a factor of 1.2 to account for the time needed for setup, adjustment, and to move the equipment to the blackberry field (Edwards, 2001). Hired employees were paid $\$ 8.25 / \mathrm{h}$ while the owner/ operator was compensated at a rate of $\$ 16.39 / \mathrm{h}$ and are meant to be representative of the "true" costs of labor and not just the base wage rate. These labor rates include a base wage rate of $\$ 7.75 / \mathrm{h}$ and $\$ 13.00 / \mathrm{h}$ for the hired employees and owner/operator, respectively, plus the required payroll expenses (e.g., workers' compensation, unemployment, and FICA taxes, and other overhead expenses). The average wage rate for farm labor hired to perform field work in the southeastern U.S. was $\$ 7.75 /$ h from Jan. to Oct. 2003 (North Carolina Department of Agriculture and Consumer Services, 2003) and it was assumed that the owner/operator could earn at least $\$ 13.00 / \mathrm{h}$ at his/her "next best" employment opportunity.

For purposes of this study, it was assumed that all the machinery and equipment were purchased new at 2003 purchase prices. The machinery and equipment used in this budget reflect machinery components that can be used for other farming enterprises in addition to growing blackberries on a typical diversified farm. Therefore, the hours of annual use and the resulting costs per hour reflect the equipment costs for a total farm business and not just for blackberry production. The exceptions to this are the fumigation and irrigation equipment, which was used solely for blackberry production and the refrigeration equipment, which is needed to maintain fruit quality during storage and transportation to the wholesale market.

The prices of the materials used to produce blackberries were obtained from local dealers who regularly supply North Carolina blackberry growers. Prices for the blackberry plants were obtained from a nursery in the southeastern U.S. that has certified virus-indexed plant material. It was also assumed that two cultivars were planted to extend the harvest season to 6 to 8 weeks. Materials for insect, disease, and weed control were based on recommendations in the 2005 North Carolina Agricultural Chemicals Manual (North Carolina State University, 2005), although specific chemicals are not listed in this budget by name. Fumigation and black plastic were an integral part of the weed control program, so it was assumed that their use minimized the weed population. However, a herbicide program was also developed to help control the weed population. Fertilization followed recommended rates; however, the fertilizer was delivered via a drip irrigation system from March through May. A detailed list of supplies for the trellis used in this budget (Stiles shift trellis) can be found elsewhere (Stiles, 1999).

Since every commodity should contribute to the financial success of a farm, a fee was charged to the blackberry enterprise for the overall farm overhead expenses and operating capital. Because land values vary throughout the region a land charge was not included in this budget. However, growers should include a land charge that is representative of current land values in their region. Owners should also charge a management fee to the enterprise to account for their managerial ability in supervising the overall operation.

The harvest season was assumed to last 6 to 8 weeks. It is important to understand that the marketing process bears a cost and that this marketing cost will vary considerably depending on the marketing system that producers decide to use. For growers who market their fruit through direct market operations, the out-of-pocket cost might be relatively little compared to the costs incurred when selling blackberries through conventional wholesale market channels. In this study it was assumed that half of the fruit would be sold at the farm through a PYO operation and half would be sold through wholesale marketing channels. It was also assumed that the owner/operator supervised the overall harvest operations. Supervisory tasks included helping PYO customers, monitoring the PYO checkout operations, overseeing the hired pickers, directing the postharvest handling of the fruit destined for the wholesale market as well as the general management of the blackberry operation. If the individual who must be available to accomplish these tasks has an alternative use for his or her labor, the foregone income from this alternative is a valid cost and the labor costs for supervision should be adjusted accordingly.

\section{Results and discussion}

Capital investment for the machinery and equipment for the establishment and operation of the blackberry planting were estimated to be $\$ 63,650, \$ 18,956$, and $\$ 10,225$ for the preparatory, first, and second years, respectively (Table 1). Purchase of most of the equipment for land preparation and planting occur in the preparation year and the first year of production. The fruit scales and the refrigeration equipment needed to store and transport the berries can be delayed until the first harvest in the second year of production. The portable forced-air cooling unit (FACU) was assumed to be constructed in accordance with the cooling unit designed at North Carolina State University (Boyette, 1995). The FACU was designed to fit in a standard-size pickup truck and is used to keep the berries cool as the fruit is being transported to the wholesale market.

The expected yield pattern over the 10-year life of the blackberry planting assumed no adverse weather, production setbacks, or marketing difficulties starting in year 0 (preparation year) as illustrated in Table 2 . The initial yield in the second year was 10,000 $\mathrm{lb} / \mathrm{acre}$, with production peaking at $12,500 \mathrm{lb} /$ acre in the third through ninth years and dropping to 10,000 $\mathrm{lb} /$ acre in the last year of harvest.

The costs of preparing the land for planting, establishing the blackberry planting, and growing, harvesting and marketing blackberries are listed in Table 3. Assembling the plants and 
Table 1. Estimated purchase prices and annual hours of use for the machinery and equipment needed to establish and maintain a blackberry planting over the life of the planting on a farm in the southeastern U.S. with a $50 \%$ pick-your-own (PYO) and 50\% wholesale marketing operation.

\begin{tabular}{|c|c|c|c|c|c|}
\hline \multirow{2}{*}{$\begin{array}{l}\text { Production year } \\
\text { in which the item } \\
\text { was purchased }\end{array}$} & \multirow{2}{*}{$\begin{array}{c}\text { Equipment or } \\
\text { machinery item } \\
\text { purchased }\end{array}$} & \multirow{2}{*}{$\begin{array}{l}\text { Estimated } \\
\text { annual } \\
\text { usage }(\mathrm{h})\end{array}$} & \multirow{2}{*}{$\begin{array}{c}\text { Estimated } \\
\text { purchase } \\
\text { price }(\$) \\
\end{array}$} & $\begin{array}{l}\text { Production } \\
\text { year }\end{array}$ & $\begin{array}{l}\text { Projected annual } \\
\text { yield }\left(\mathrm{lb} / \mathrm{acre}^{\mathrm{z}}\right)\end{array}$ \\
\hline & & & & $0^{y}$ & 0 \\
\hline \multirow{8}{*}{$\begin{array}{l}\text { Preparation } \\
\text { year }\end{array}$} & Tractor, 60 horsepower $^{\mathrm{z}}$ & 500 & 25,300 & 1 & 0 \\
\hline & Pickup truck, $1 / 2$ ton $^{y}$ & 650 & 25,000 & 2 & 10,000 \\
\hline & Boom sprayer & 100 & 750 & 3 & 12,500 \\
\hline & Chisel plow, $7 \mathrm{ft}^{\mathrm{x}}$ & 125 & 3,000 & 4 & 12,500 \\
\hline & Disk, $9 \mathrm{ft}$, two row & 125 & 5,000 & 5 & 12,500 \\
\hline & Rotary mower, $7 \mathrm{ft}$ & 150 & 2,600 & 6 & 12,500 \\
\hline & Irrigation well & 150 & 2,000 & 7 & 12,500 \\
\hline & Total preparation year & --- & $\$ 63,650$ & 8 & 12,500 \\
\hline \multirow[t]{7}{*}{1} & Plastic layer/fumigator & 10 & 7,000 & 9 & 12,500 \\
\hline & Soil auger & 6 & 425 & 10 & 10,000 \\
\hline & Drip irrigation system and pump & 40 & 6,031 & \multirow{5}{*}{\multicolumn{2}{|c|}{$\begin{array}{l}\mathrm{z} 1.0 \mathrm{lb} / \mathrm{acre}=1.1209 \mathrm{~kg} \cdot \mathrm{ha}^{-1} \\
{ }^{\mathrm{y}} \text { Year } 0=\text { preparation year. }\end{array}$}} \\
\hline & Fertilizer injector & 40 & 400 & & \\
\hline & Utility trailer & 100 & 2,000 & & \\
\hline & $\mathrm{PTO}^{\mathrm{w}}$ blast sprayer & 125 & 3,100 & & \\
\hline & Total first year & --- & $\$ 18,956$ & & \\
\hline \multirow[t]{4}{*}{2} & Fruit scale for PYO operation & 2 & 225 & & \\
\hline & Utility refrigerators $(2)$ & 3,672 & 5,000 & & \\
\hline & Portable FACUs ${ }^{v}(2)$ & 3,672 & 5,000 & & \\
\hline & Total second year & -- & $\$ 10,225$ & & \\
\hline
\end{tabular}

Table 3. Estimated costs per acre needed to produce, harvest and market blackberries for a 50\% pick-your-own (PYO) and $\mathbf{5 0 \%}$ wholesale marketing operation on a farm in the southeastern U.S.

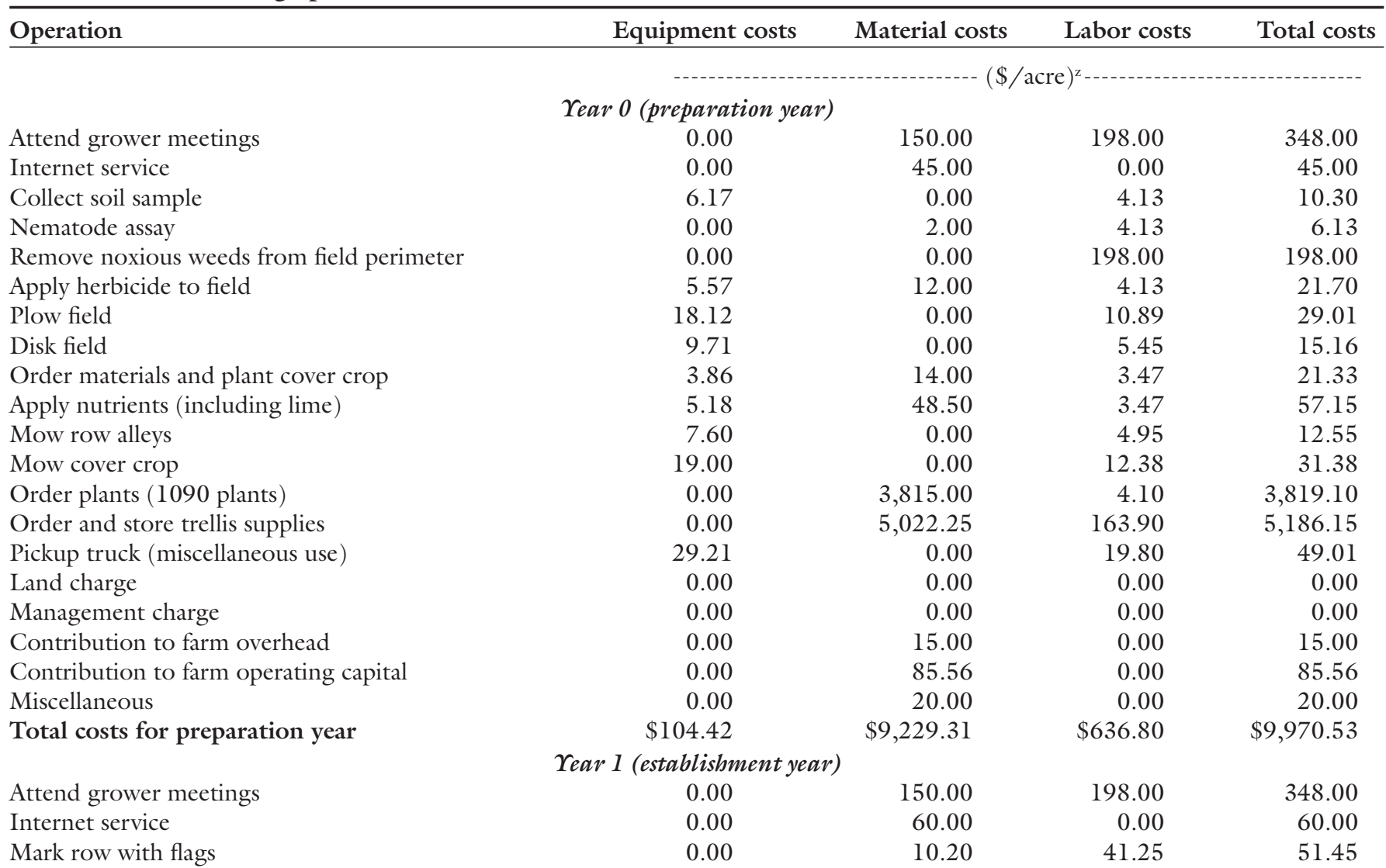

Table 3 continued on next page.

Table 2. Projected annual blackberry yields for an 11-year production period on a farm in the southeastern

U.S.

0.00

0.00

9.71

7.60

0.00

0.00

0.00

0.00

0.00

10.20
48.00

6.13

1.70

1.33

2.55

1.38

186.15

9.01

0.00

5.00

0.00

48.00

51.45 . 
Table 3. Continued from previous page.

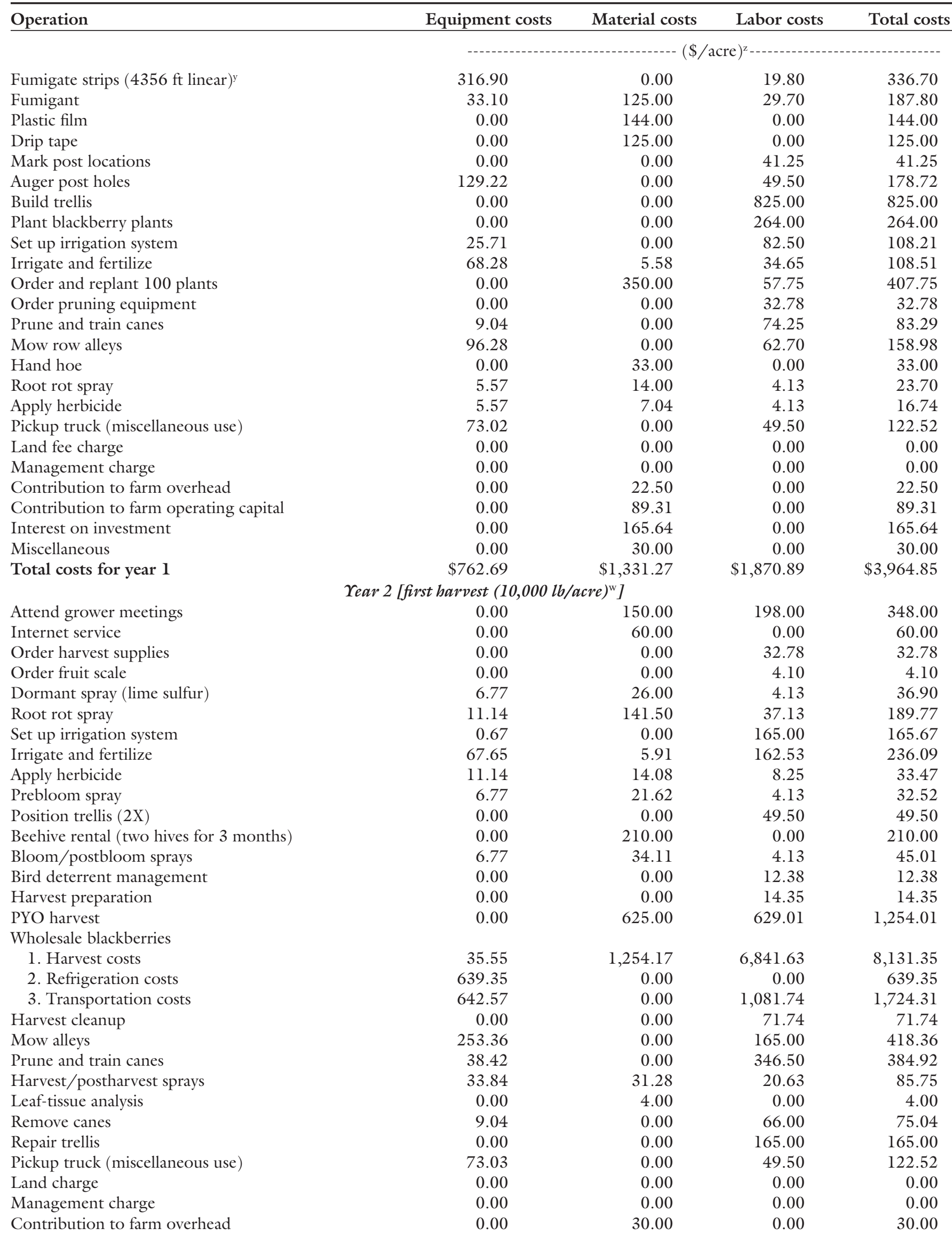

Table 3 continued on next page. 
Table 3. Continued from previous page.

Operation

Equipment costs

Material costs

Labor costs

Total costs

Contribution to farm operating capital

Interest on investment

Miscellaneous

Total costs for year 2

Attend grower meetings

Internet service

Order harvest supplies

Dormant spray

Root rot spray

Set up irrigation system

Irrigate and apply fertilizer

Apply herbicide

Prebloom spray

Position trellis $(2 \mathrm{X})$

Beehive rental (two hives for 3 months)

Bloom/postbloom spray

Bird deterrent management

Harvest preparation

PYO harvest

Wholesale blackberries

1. Harvest costs

2. Refrigeration costs

3. Transportation costs

Harvest cleanup

Mow alleys

Prune and train canes

Harvest/postharvest sprays

Leaf-tissue analysis

Remove canes

Repair trellis

Pickup truck (miscellaneous use)

Land charge

Management charge

Contribution to farm overhead

Contribution to farm operating capital

Interest on investment

Miscellaneous

Total costs year 3

Total costs year 4

Total costs year 5

Total costs year 6

Total costs year 7

Total costs year 8

Total costs year 9

Total costs year 10

Total estimated costs

${ }^{\mathrm{z}} \$ 1.00 /$ acre $=\$ 2.471 \mathrm{l} / \mathrm{ha}$.

${ }^{\mathrm{y}} 1 \mathrm{ft}=0.3048 \mathrm{~m}$.

${ }^{\mathrm{w}} 1.0 \mathrm{lb} / \mathrm{acre}=1.1209 \mathrm{~kg} \cdot \mathrm{ha}^{-1}$.

(\$ $/$ acre $)^{z}$

$\begin{array}{rrrr}0.00 & 61.29 & 0.00 & 61.29 \\ 0.00 & 836.04 & 0.00 & 836.04 \\ 0.00 & 40.00 & 0.00 & 40.00\end{array}$

$\$ 1,836.07 \quad \$ 3,545.00$

Year 3 [full production $(12,500 \mathrm{lb} / \text { acre })^{\mathrm{w}}$ ]

0.00

0.00

0.00

6.77

11.14

0.67

58.79

11.14

6.77

0.00

0.00

6.77

0.00

0.00

0.00

35.55

639.35

700.98

0.00

253.36

38.42

33.84

0.00

9.04

0.00

58.42

0.00

0.00

0.00

0.00

0.00

0.00

$\$ 1,871.01$

rear 4

$\$ 1,871.01$

rear 5

$\$ 1,871.01$

rear 6

$\$ 1,871.01$

rear 7

$\$ 1,871.01$

rear 8

$\$ 1,871.01$

rear 9

$\$ 1,871.01$

rear 10

$\$ 1,836.07$

$\$ 17,636.32$
150.00

60.00

0.00

26.00

141.50

0.00

8.52

14.07

21.62

0.00

140.00

35.97

0.00

0.00

781.25

$1,567.71$

0.00

0.00

0.00

0.00

0.00

31.28

4.00

0.00

0.00

0.00

0.00

0.00

30.00

63.29

836.04

40.00

$\$ 3,951.25$

$\$ 3,951.25$

$\$ 3,951.25$

$\$ 3,951.25$

$\$ 3,951.25$

$\$ 3,951.25$

$\$ 3,951.25$

$\$ 3,544.99$

$\$ 45,309.32$
$\$ 10,133.16$

198.00

0.00

32.78

4.13

37.13

165.00

158.81

8.25

4.13

49.50

0.00

4.13

12.38

16.50

738.21

$10,244.52$

0.00

$1,180.08$

82.50

165.00

346.50

20.63

0.00

66.00

165.00

39.60

0.00

0.00

0.00

0.00

0.00

0.00

$\$ 13,738.78$

$\$ 13,738.78$

$\$ 13,738.78$

$\$ 13,738.78$

$\$ 13,738.78$

$\$ 13,738.78$

$\$ 13,738.78$

$\$ 10,133.16$

$\$ 118,945.47$
$\$ 15,514.23$

348.00

60.00

32.78

36.90

189.77

165.67

226.13

33.46

32.52

49.50

140.00

46.87

12.38

16.50

$1,519.46$

$11,847.78$

639.35

$1,881.06$

82.50

418.36

384.92

85.75

4.00

75.04

165.00

98.02

0.00

0.00

30.00

63.29

836.04

40.00

$\$ 19,561.04$

$\$ 19,561.04$

$\$ 19,561.04$

$\$ 19,561.04$

$\$ 19,561.04$

$\$ 19,561.04$

$\$ 19,561.04$

$\$ 15,514.23$

$\$ 181,891.11$ 
supplies and preparing the land for planting during the preparation year was estimated to cost $\$ 9970 /$ acre while establishing the planting in the first production year cost $\$ 3965 /$ acre .

The total cost of producing, harvesting, and marketing the blackberries was estimated to be $\$ 15,514 /$ acre if the marketable yield was $10,000 \mathrm{lb} /$ acre and $\$ 19,561 /$ acre if the yield was $12,500 \mathrm{lb} /$ acre. Not surprisingly, the cost of the materials accounted for the largest percentage of the total costs during the preparation year, comprising $92 \%$ of the total costs. However, labor was the most expensive cost category in the establishment year and after the planting started producing fruit. Labor expenses totaled $\$ 1870 /$ acre, or $47 \%$ of the total costs in the establishment year; $\$ 10,133 /$ acre, or $65 \%$ of the total costs, when the marketable yield was $10,000 \mathrm{lb} /$ acre; and $\$ 13,739 /$ acre, or $70 \%$ of the total costs, when the marketable yield was $12,500 \mathrm{lb} /$ acre. Overall the cost of owning and operating the machinery and equipment accounted for $9.7 \%$ of the total costs during the 10-year life of the blackberry planting, while the materials expense represented $24.9 \%$ of the total and labor expenses made up $65.4 \%$ of the total costs.

Monthly expenses. The estimated monthly expenses for the major cost categories were included to give growers an idea of the potential annual cash flow obligations (Table 4). Growers should estimate these monthly cash flow requirements before planting blackberries to ensure that they know how much money must be available to meet their financial obligations. In addition, a lending agency may require the grower to provide information to determine the appropriate repayment schedule if the grower has to secure a financial loan.

Over $88 \%$ of the total estimated cost in the preparation year was spent in December to purchase the blackberry plants and the trellis supplies. Constructing the trellis and planting the blackberry plants in March and April accounted for $30.0 \%$ and $38.7 \%$, respectively, of the total cost per acre in the first year. The costs associated with harvesting and marketing blackberries were the most expensive cost categories when the planting started producing fruit. When the marketable yield was projected to be $10,000 \mathrm{lb} /$ acre in the second year and last year of production, the costs were estimated to be $\$ 5459$ in May and \$5290 in June, which was $35.2 \%$ and $34.1 \%$, respectively, of the total annual costs. In the third through the ninth years, the projected expense in May was $\$ 7205$, or $36.8 \%$ of the total annual costs, and \$7132 in June, or $36.5 \%$ of the total. In addition, labor expenditures accounted for over $82 \%$ of the monthly harvesting and marketing costs when the blackberry planting yielded $10,000 \mathrm{lb} /$ acre of berries and over $87 \%$ of the total expenses when $12,500 \mathrm{lb}$ of marketable fruit was harvested per acre.

Monthly LABOR estimates. Since blackberries are a labor-intensive enterprise, the annual labor estimates are presented in Table 5 to give potential growers an idea of the amount of labor that will be required each month to maintain, harvest and market this crop. It is not surprising that the required person-hours of labor increase each year until the blackberry planting reaches full production in the third year and then decreases as the marketable yield declines. May is the most labor-intensive month during the preparation year as the field is prepared for planting. During the establishment year, or first year of production, March and April require the vast majority of the labor when the trellis is being constructed and the blackberry plants are being planted. May and June are the most labor-intensive months when the blackberries are being harvested and marketed. A total of 981 .6 personhours, or $87.6 \%$ of the total annual labor, are estimated to be needed in these months during the second year; and 1265.2 person-hours, or $90.2 \%$ of the annual total, are required during the third through ninth years of production. However, if the assumption of selling half the crop to wholesale markets is changed, the amount of labor that is needed will depend on the percentage of fruit that is sold to the direct and wholesale markets.

RETURNS TO LAND AND MANAGEMENT. The net returns to land and management will depend on the marketable yield and the price growers receive for their blackberries. As in most farming operations, growers do have a tremendous influence on their crop yields. The more they know about their crop and the better job they do in caring for the crop, the more likely they will have higher yields of high- quality fruit. However, local markets will determine the maximum price for which growers can sell their berries. Since prices and yields can vary significantly from one location to another, the projected net returns shown in Table 6 were calculated for various combinations of prices and marketable yields.

Gross revenues were calculated assuming that farmers will try to sell as much fruit as possible. The blackberry prices and projected yields were obtained from the blackberry growers who reviewed this enterprise budget. PYO prices ranged from a low of $\$ 1.15 / \mathrm{lb}$ to a high of $\$ 1.35 / \mathrm{lb}$ while the lowest wholesale price was $\$ 2.00 / \mathrm{lb}$ and the highest price was $\$ 3.00 / \mathrm{lb}$. Yield estimates ranged from a low of $8500 \mathrm{lb} /$ acre to a high of $16,500 \mathrm{lb} /$ acre during the planting's peak production period in the third through the 10 th years. Total expenses per acre were adjusted to account for varying the yields.

If the marketable yield was 8500 $\mathrm{lb} /$ acre, growers would not receive a positive return unless the PYO price was $\$ 1.35 / \mathrm{lb}$ and the wholesale price was $\$ 3.00 / \mathrm{lb}$. Similarly, if the yield was $10,500 \mathrm{lb} /$ acre, the PYO price had to be at least $\$ 1.25 / \mathrm{lb}$ and the wholesale price had to be $\$ 2.50 / \mathrm{lb}$ to achieve a positive return. Positive returns to land and management were projected for all other combinations of prices and yields used in this study.

This analysis also revealed that growers would not achieve a positive net return if they received a price combination of $\$ 1.15 / \mathrm{lb}$ for their PYO berries and $\$ 2.00 / \mathrm{lb}$ for the wholesale berries unless the marketable yield was almost $12,500 \mathrm{lb} /$ acre (Table 6). In fact, the breakeven yield for this price combination was 12,402 $\mathrm{lb} /$ acre (Table 7 ). If the PYO price was $\$ 1.25 / \mathrm{lb}$ and the wholesale price was $\$ 2.50 / \mathrm{lb}$, the breakeven yield was $10,066 \mathrm{lb} /$ acre, while the price combination of $\$ 1.35 / \mathrm{lb}$ at the PYO operation and $\$ 3.00 / \mathrm{lb}$ at the wholesale market resulted in a breakeven yield of $8470.5 \mathrm{lb} /$ acre.

BLACKBERRY PROFITABILITY. When judging the profitability of an enterprise, it is important to see not only how many dollars the enterprise yields, but also when the dollars come in and the returns are available for other enterprises. There are two principles to consider. First, the sooner a dollar of revenue comes in, the sooner it can be used to earn more revenue. Secondly, for any two enterprises of equal risk, 
Table 4. Estimated monthly and annual equipment, material, labor, and total cost of producing, harvesting, and marketing blackberries for a $50 \%$ pick-your-own and $50 \%$ wholesale marketing operation on a farm in the southeastern U.S. ${ }^{z}$

\begin{tabular}{|c|c|c|c|c|c|}
\hline $\begin{array}{l}\text { Year and month } \\
\text { the costs are incurred }\end{array}$ & $\begin{array}{c}\text { Estimated } \\
\text { equipment } \\
\text { costs }\end{array}$ & $\begin{array}{c}\text { Estimated } \\
\text { material } \\
\text { costs }\end{array}$ & $\begin{array}{c}\text { Estimated } \\
\text { labor } \\
\text { costs }\end{array}$ & $\begin{array}{c}\text { Estimated } \\
\text { total } \\
\text { costs }\end{array}$ & $\begin{array}{c}\text { Monthly } \\
\text { percentage } \\
\text { of total costs }\end{array}$ \\
\hline \multirow{2}{*}{\multicolumn{6}{|c|}{ Proparation $)^{\mathrm{y}}$}} \\
\hline & & & & & \\
\hline January & 0.00 & 0.00 & 0.00 & 0.00 & 0.00 \\
\hline February & 0.00 & 150.00 & 198.00 & 348.00 & 3.49 \\
\hline May & 50.04 & 79.50 & 230.38 & 359.92 & 3.61 \\
\hline June & 4.75 & 5.00 & 3.09 & 12.84 & 0.13 \\
\hline July & 4.75 & 5.00 & 3.09 & 12.84 & 0.13 \\
\hline August & 4.75 & 5.00 & 3.09 & 12.84 & 0.13 \\
\hline September & 4.75 & 5.00 & 3.09 & 12.84 & 0.13 \\
\hline October & 0.00 & 5.00 & 0.00 & 5.00 & 0.05 \\
\hline \multicolumn{6}{|c|}{ Year 1} \\
\hline January & 0.00 & 5.00 & 0.00 & 5.00 & 0.13 \\
\hline February & 0.00 & 165.20 & 239.25 & 404.45 & 10.20 \\
\hline March & 386.03 & 400.97 & 403.84 & $1,190.84$ & 30.03 \\
\hline April & 151.28 & 356.97 & $1,027.32$ & $1,535.56$ & 38.73 \\
\hline May & 67.39 & 39.64 & 57.34 & 164.37 & 4.15 \\
\hline June & 19.54 & 5.00 & 25.16 & 49.70 & 1.25 \\
\hline July & 27.14 & 5.00 & 30.11 & 62.25 & 1.57 \\
\hline August & 19.55 & 5.00 & 25.17 & 49.72 & 1.25 \\
\hline September & 18.74 & 26.04 & 13.20 & 57.98 & 1.46 \\
\hline October & 0.00 & 5.00 & 0.00 & 5.00 & 0.13 \\
\hline November & 0.00 & 5.00 & 0.00 & 5.00 & 0.13 \\
\hline December & 0.00 & 5.00 & 0.00 & 5.00 & 0.13 \\
\hline June & 795.98 & 106.28 & $4,387.48$ & $5,289.73$ & 34.10 \\
\hline July & 69.40 & 9.00 & 244.57 & 322.97 & 2.08 \\
\hline August & 64.88 & 5.00 & 69.71 & 139.59 & 0.90 \\
\hline September & 10.09 & 132.50 & 66.00 & 208.59 & 1.34 \\
\hline October & 5.57 & 12.04 & 4.13 & 21.74 & 0.14 \\
\hline November & 0.00 & 5.00 & 165.00 & 170.00 & 1.10 \\
\hline December & 0.00 & 5.00 & 0.00 & 5.00 & 0.03 \\
\hline Annual charges & 73.02 & 967.33 & 49.50 & $1,089.85$ & 7.02 \\
\hline Total year 2 & $\$ 1,836.07$ & $\$ 3,545.00$ & $\$ 10,133.16$ & $\$ 15,514.23$ & \\
\hline \multicolumn{6}{|c|}{ Years 3-9 } \\
\hline January & 5.65 & $2,353.96$ & 74.03 & $2,433.64$ & 12.44 \\
\hline February & 5.65 & 155.00 & 239.25 & 399.90 & 2.04 \\
\hline March & 27.88 & 54.87 & 105.60 & 188.35 & 0.96 \\
\hline April & 16.74 & 99.46 & 138.60 & 254.81 & 1.30 \\
\hline May & 751.53 & 113.81 & $6,339.66$ & $7,205.00$ & 36.83 \\
\hline June & 854.37 & 36.28 & $6,241.87$ & $7,132.52$ & 36.46 \\
\hline July & 69.40 & 9.00 & 255.33 & 333.73 & 1.71 \\
\hline August & 65.71 & 5.00 & 69.71 & 140.42 & 0.72 \\
\hline September & 10.09 & 132.50 & 66.00 & 208.59 & 1.07 \\
\hline October & 5.57 & 12.04 & 4.13 & 21.73 & 0.11 \\
\hline November & 0.00 & 5.00 & 165.00 & 170.00 & 0.87 \\
\hline December & 0.00 & 5.00 & 0.00 & 5.00 & 0.03 \\
\hline Annual charges & 58.42 & 969.33 & 39.60 & $1,067.35$ & 5.46 \\
\hline Total years 3-9 & $\$ 1,871.01$ & $\$ 3,951.25$ & $\$ 13,738.78$ & $\$ 19,561.04$ & \\
\hline
\end{tabular}

${ }^{z}$ Some values may not total due to rounding error.

y $\$ 1.00 /$ acre $=\$ 2.4711 /$ ha. 
Table 5. Estimated monthly and annual labor required to grow, harvest, and market blackberries for a $50 \%$ pick-your-own and $50 \%$ wholesale marketing operation on a farm in the southeastern U.S.

\begin{tabular}{|c|c|c|}
\hline $\begin{array}{l}\text { Production } \\
\text { year }\end{array}$ & Month & $\begin{array}{c}\text { Estimated labor } \\
\text { required } \\
\text { (person-hours) }\end{array}$ \\
\hline \multirow{13}{*}{$\begin{array}{l}\text { Preparation } \\
\text { year }\end{array}$} & January & 0.00 \\
\hline & February & 24.00 \\
\hline & March & 0.00 \\
\hline & April & 1.00 \\
\hline & May & 27.92 \\
\hline & June & 0.38 \\
\hline & July & 0.38 \\
\hline & August & 0.38 \\
\hline & September & 0.38 \\
\hline & October & 0.00 \\
\hline & November & 0.00 \\
\hline & December & 10.25 \\
\hline & General activities & 2.40 \\
\hline \multicolumn{2}{|c|}{$\begin{array}{l}\text { Total estimated annual labor for th } \\
\text { preparation year }\end{array}$} & 67.09 \\
\hline \multirow[t]{13}{*}{ Year 1} & January & 0.00 \\
\hline & February & 29.00 \\
\hline & March & 48.95 \\
\hline & April & 122.55 \\
\hline & May & 6.95 \\
\hline & June & 3.05 \\
\hline & July & 3.65 \\
\hline & August & 3.05 \\
\hline & September & 1.60 \\
\hline & October & 0.00 \\
\hline & November & 0.00 \\
\hline & December & 0.00 \\
\hline & General activities & 6.00 \\
\hline \multicolumn{2}{|c|}{$\begin{array}{l}\text { Total estimated annual labor for } \\
\text { year } 1\end{array}$} & 224.80 \\
\hline \multirow[t]{13}{*}{ Year 2} & January & 7.25 \\
\hline & February & 29.00 \\
\hline & March & 12.80 \\
\hline & April & 16.54 \\
\hline & May & 499.93 \\
\hline & June & 481.62 \\
\hline & July & 29.65 \\
\hline & August & 8.45 \\
\hline & September & 8.00 \\
\hline & October & 0.50 \\
\hline & November & 20.00 \\
\hline & December & 0.00 \\
\hline & General activities & 6.00 \\
\hline \multicolumn{2}{|c|}{$\begin{array}{l}\text { Total estimated annual labor for } \\
\text { year } 2\end{array}$} & $1,119.74$ \\
\hline \multirow[t]{13}{*}{ Years 3-9 } & January & 7.00 \\
\hline & February & 29.00 \\
\hline & March & 12.80 \\
\hline & April & 16.80 \\
\hline & May & 638.80 \\
\hline & June & 626.45 \\
\hline & July & 30.95 \\
\hline & August & 8.45 \\
\hline & September & 8.00 \\
\hline & October & 0.50 \\
\hline & November & 20.00 \\
\hline & December & 0.00 \\
\hline & General activities & 4.80 \\
\hline \multicolumn{2}{|c|}{$\begin{array}{l}\text { Total estimated annual labor for } \\
\text { years 3-9 }\end{array}$} & $1,403.55$ \\
\hline
\end{tabular}

Table 6. Estimated returns to land and management for varying pickyour-own and wholesale prices and marketable yields received by farmers from growing, harvesting, and marketing blackberries for a $\mathbf{5 0 \%}$ pick-your-own and $50 \%$ wholesale marketing operation on a farm in the southeastern U.S.

\begin{tabular}{|c|c|c|c|c|c|c|}
\hline \multirow{2}{*}{$\begin{array}{l}\text { Pick-your- } \\
\text { own price } \\
(\$ / \text { lb })^{\mathrm{y}}\end{array}$} & \multirow{2}{*}{$\begin{array}{c}\text { Wholesale } \\
\text { price } \\
(\$ / 1 b)\end{array}$} & \multicolumn{5}{|c|}{ Marketable yields (lb/acre $)^{\mathrm{z}}$} \\
\hline & & 8,500 & 10,500 & 12,500 & 14,500 & 16,500 \\
\hline & & \multicolumn{5}{|c|}{----Returns for the marketable yields $(\$ / \text { acre })^{\mathrm{x}}$---- } \\
\hline 1.15 & 2.00 & $-5,044$ & $-2,459$ & 126 & 2,712 & 5,297 \\
\hline 1.20 & 2.25 & $-3,769$ & -884 & 2,001 & 4,887 & 7,772 \\
\hline 1.25 & 2.50 & $-2,494$ & 691 & 3,876 & 7,062 & 10,247 \\
\hline 1.30 & 2.75 & $-1,219$ & 2,266 & 5,751 & 9,237 & 12,722 \\
\hline 1.35 & 3.00 & 56 & 3,841 & 7,626 & 11,412 & 15,197 \\
\hline
\end{tabular}

${ }^{\mathrm{z}} 1 \mathrm{lb} / \mathrm{acre}=1.1209 \mathrm{~kg} \cdot \mathrm{ha}^{-1}$.

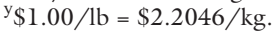

$\mathrm{x} \$ 1.00 / \mathrm{acre}=\$ 2.4711 / \mathrm{ha}$.

Table 7. The estimated breakeven yields per acre ${ }^{\mathrm{z}}$ that must be sold to cover production, harvesting and marketing costs for 1 acre $(0.4 \mathrm{ha})$ of blackberries for various price combinations assuming a $\mathbf{5 0 \%}$ pick-your-own and $50 \%$ wholesale marketing operation on a farm in the southeastern U.S.

\begin{tabular}{lcc}
\hline $\begin{array}{l}\text { Pick-your- } \\
\text { own price } \\
(\$ / 1 \mathrm{~b})^{\mathrm{y}}\end{array}$ & $\begin{array}{c}\text { Wholesale } \\
\text { price } \\
(\$ / 1 \mathrm{~b})\end{array}$ & $\begin{array}{c}\text { Breakeven yield for the } \\
\text { respective price combination } \\
(\text { lb/acre })^{\mathrm{x}}\end{array}$ \\
\hline 1.15 & 2.00 & 12,402 \\
1.20 & 2.25 & 11,112 \\
1.25 & 2.50 & 10,066 \\
1.30 & 2.75 & 9,199 \\
1.35 & 3.00 & 8,470 \\
\hline
\end{tabular}

${ }^{2}$ The breakeven yield was calculated by setting net returns equal to zero. Therefore the returns above the breakeven yield are the revenues available to cover the land and management fees as well as profit.

y $\$ 1.00 / \mathrm{lb}=\$ 2.2046 / \mathrm{kg}$.

${ }^{\mathrm{x}} 1.0 \mathrm{lb} / \mathrm{acre}=1.1209 \mathrm{~kg} \cdot \mathrm{ha}^{-1}$

the one yielding the higher rate of return is usually preferable. We will look at the flow of funds in the blackberry business to show both profitability and cash position (solvency).

After subtracting expenses from revenues in each year, the flowof-funds, or net cash flow, pattern emerges as it appears in Table 8 . Farmers establishing new blackberry plantings will experience net outflows of cash during the first 2 years. The income stream becomes positive during the second year of production when fruit is harvested and increases slightly in the third year when the yield increases.

The net accumulated cash flow is also shown in Table 8 . The fifth year is the year of payback, that is, the year in which growers finally get their investment back in terms of cash flow. The payback year or breakeven year is an important consideration in arranging financing because farmers must secure loans that cover the period in which the enterprise operates in a deficit cash position. Only during the breakeven year will enough revenues have been generated to cover start-up expenses.

The next step is to compare the net revenue stream with other opportunities. There are two ways to do this. The first way is to assume that farmers could invest their money elsewhere at a given interest rate, such as $6 \%$, and compare the blackberry enterprise with this other investment. The interest rate selected for this analysis should represent the "best" low risk alternative, such as a long-term certificate of deposit, available for off-farm investments. For a single enterprise, the essence of the net present value (NPV) approach is that the project should be accepted if its NPV is greater than zero. This procedure uses the discounting procedure to compare the value of a dollar at the time of the 
Table 8. Estimated annual yields, gross revenues, costs, net and accumulated cash flows for 1 acre ( 0.4 ha) of blackberries over an 11 -year production period, starting with the establishment year and ending after nine seasons of fruit production, for a representative farm in the southeastern U.S. with a $50 \%$ pick-yourown and $50 \%$ wholesale marketing operation. ${ }^{z}$

\begin{tabular}{lcrrrr}
\hline $\begin{array}{l}\text { Production } \\
\text { year }\end{array}$ & $\begin{array}{c}\text { Estimated } \\
\text { annual } \\
\text { yield }\end{array}$ & $\begin{array}{c}\text { Estimated } \\
\text { gross } \\
\text { revenue }\end{array}$ & $\begin{array}{c}\text { Estimated } \\
\text { costs }^{\mathrm{x}}\end{array}$ & $\begin{array}{c}\text { Net cash } \\
\text { flow }\end{array}$ & $\begin{array}{c}\text { Accumulated } \\
\text { Net cash }\end{array}$ \\
\hline $0^{\mathrm{w}}$ & - & & & & \\
1 & 0 & 0.00 & $9,970.53$ & $-9,970.53$ & $-9,970.53$ \\
2 & 0 & 0.00 & $3,964.85$ & $-3,964.85$ & $-13,935.38$ \\
3 & 10,000 & $18,750.00$ & $15,514.23$ & $3,235.77$ & $-10,699.61$ \\
4 & 12,500 & $23,437.50$ & $19,561.04$ & $3,876.46$ & $-6,823.15$ \\
5 & 12,500 & $23,437.50$ & $19,561.04$ & $3,876.46$ & $-2,946.69$ \\
6 & 12,500 & $23,437.50$ & $19,561.04$ & $3,876.46$ & 929.77 \\
7 & 12,500 & $23,437.50$ & $19,561.04$ & $3,876.46$ & $4,806.23$ \\
8 & 12,500 & $23,437.50$ & $19,561.04$ & $3,876.46$ & $8,682.69$ \\
9 & 12,500 & $23,437.50$ & $19,561.04$ & $3,876.46$ & $12,559.15$ \\
10 & 12,500 & $23,437.50$ & $19,561.04$ & $3,876.46$ & $16,435.61$ \\
\hline
\end{tabular}

${ }^{2}$ The prices used to calculate the gross revenues were $\$ 1.25 / \mathrm{lb}(\$ 2.7557 / \mathrm{kg})$ for the pick-your-own blackberries and $\$ 2.50 / \mathrm{lb}(\$ 5.5115 / \mathrm{kg})$ for the berries sold at the wholesale market.

s $\$ 1.00 /$ acre $=\$ 2.4711 /$ ha .

xEstimated costs do not include a land charge or management fee.

wYear $0=$ preparation year.

planting decision with a dollar received for blackberries at some future time. Discounting is based on the concept that a dollar received in the future is worth less than a dollar received today. For example, $\$ 1000$ received 10 years from now is worth $\$ 558$ received today at a $6 \%$ interest rate.

Today's cash equivalent value of applying land and management to blackberries for a $6 \%$ interest rate is $\$ 10,235$. The figure is interpreted in just one way, but the interpretation can be phrased in several ways. At an interest rate of $6 \%$, for example: 1) a new, 1-acre blackberry planting is worth $\$ 10,235$ today; and 2 ) if a farmer was just about to establish a blackberry planting, someone would have to pay him $\$ 10,235$ to bribe him to forget the plans. Under these assumptions, blackberry planting is a winning proposition.

The second method for financial comparison of the blackberry enterprise with other opportunities is to calculate the internal rate of return (IRR) on the total investment in blackberries and then compare this rate of return with the interest yields on other investments. In this analysis, blackberry production was compared to U.S. Treasury bonds, which are typically a 20 -year low risk investment. The IRR to an invest- ment in the blackberry enterprise was $18.4 \%$. With dividends on U.S. Treasury bonds currently yielding around $4.25 \%$, this return looks pretty good. Of course, potential growers should be cautious because revenues from blackberry production are more risky due to price fluctuations and weather conditions, but blackberry production looks profitable under the assumptions in this study.

\section{Conclusions and recommendations}

Profitability analysis revealed that blackberry production using the recommended practices can be a profitable venture. The total costs of producing, harvesting, and marketing an acre of blackberries were $\$ 19,561.04 /$ acre when planting was in full production compared to a gross revenue of $\$ 23,437.50$ (years 3-10). Therefore the estimated return to land and management for the same time period was $\$ 3,876.46 /$ acre. Cash flow analysis demonstrated that the payback period can be achieved in the fifth year, while the NPV of the investment was estimated to be $\$ 10,235$ and the IRR was $18.4 \%$.

This budget is only a guide and is not a substitute for growers calculating their own costs and breakeven year.
Costs can vary from one producer to another because of market conditions, labor supply, age and condition of the machinery and equipment, education, managerial skills, and many other factors. Since every grower's situation is different, each grower should estimate their individual production, marketing, and harvest costs based on their own production techniques, price expectations, and local market situation.

\section{Literature cited}

Boyette, M.D. 1995. Cool and ship: A low-cost portable forced air cooling unit. North Carolina Coop. Ext. Serv., N.C. State Univ., AG-7 414-7. 15 Sept. 2005. <http://www.bae.ncsu.edu/programs/ extension/publicat/postharv/ag-414 7/index.html>

Edwards, W. 2001. Estimating farm machinery costs. Iowa State Univ. Ext. PM 710. 15 Sept. 2005. <http://www.extension.iastate.edu/Publications/PM710. pdf>.

Ernst, M., T. Woods, J. Strang, and T. Jones. 2001. 2001 Kentucky blackberry cost and return estimates. Univ. of Kentucky Coop. Ext. Ser. ID=149. 15 Sept. 2005 <http://www.ca.uky.edu/agc/pubs/id/ idl49/idl49.htm>.

Perry, E.J., K.M. Klonsky, and J.J. Shimanda. 2002. Sample costs to establish and produce boysenberries. Univ. of California Coop. Ext. BB-VN-02. 15 Sept. 2005. $<$ http://coststudies.ucdavis.edu>.

North Carolina Department of Agriculture and Consumer Services. 2003. Farm labor survey-Wage rates by type of hired worker. 15 Sept. 2005. <http://www.ncagr.com/ stats/labor/labcwkyr.htm>.

North Carolina State University. 2005. 2005 North Carolina agricultural chemicals manual. North Carolina State Univ., College of Agr. and Live Sci., Raleigh. 15 Sept. 2005. <http://ipm.ncsu.edu/ agchem/agchem.html>.

Pritts, M.P. and D. Handley. 1989. Bramble production guide. Northeast Reg. Agr. Eng. Ser. NRAES-35. Ithaca, N.Y.

Stiles, H. 1999. Limited arm-rotation shift-trellis (LARS) and primocane management apparatus (PMA) for raspberries and blackberries (Rubuscvs. or crops). Va. Agr. Expt. Sta. Bul. 99-1. 15 Sept. 2005. <http://www.vaes.vt.edu/research/publications/numbered.html>. 